\title{
On the life cycle of Hemiurus levinseni Odhner, 1905 (Digenea: Hemiuridae)
}

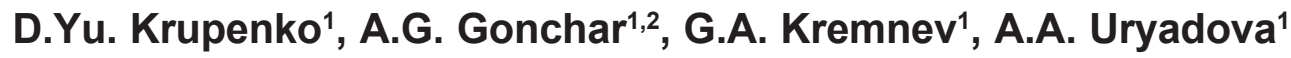

${ }^{1}$ Saint Petersburg State University, Department of Invertebrate Zoology, Universitetskaia emb., 79, Saint Petersburg, 199034, Russia.E-mail: midnightcrabb@gmail.com,d.krupenko@spbu.ru

${ }^{2}$ Zoological Institute RAS, Universitetskaia emb., 1, Saint Petersburg, 199034, Russia.

ABSTRACT: Daughter sporocysts and cystophorous cercariae were found in the gastropod Cylichna alba (Heterobranchia: Cephalaspidea) from the White Sea. By evidence from the rDNA sequences (partial 28S and 5.8S+ITS2) they match sexual adults identified as Hemiurus levinseni (Digenea: Hemiuroidea: Hemiuridae). We propose an outline of $H$. levinseni life cycle, describe morphology of its sporocysts and cercariae, and compare the latter with cercariae of other hemiuroideans. The position of the genus Hemiurus within the Hemiuridae is also discussed based on the molecular data.

How to cite this article: Krupenko D.Yu., Gonchar A.G., Kremnev G.A., Uryadova A.A. 2020. On the life cycle of Hemiurus levinseni Odhner, 1905 (Digenea: Hemiuridae) // Invert. Zool. Vol.17. No.3. P.205-218. doi: 10.15298/invertzool.17.3.01

KEY WORDS: life cycle, Digenea, Hemiuroidea, Hemiuridae, cercariae, rDNA.

\section{Жизненный цикл Hemiurus levinseni Odhner, 1905 (Digenea: Hemiuridae)}

\author{
Д.Ю. Крупенко ${ }^{1}$, А.Г. Гончар ${ }^{1,2}$, Г.А. Кремнев ${ }^{1}$, А.А. Урядова ${ }^{1}$ \\ ${ }^{1}$ Санкт-Петербургский государственный университет, кафедра зоологии беспозвоночных, \\ Университетская наб., 7-9, Санкт-Петербург, 199034, Россия. \\ E-mail:midnightcrabb@gmail.com,d.krupenko@spbu.ru \\ 2 Зоологический институт РАН, Университетская наб., 1, Санкт-Петербург, 199034, Россия.
}

РЕЗЮМЕ: В беломорских моллюсках Cylichna alba (Heterobranchia: Cephalaspidea) были обнаружены дочерние спороцисты и цистофорные церкарии. По последовательностям рДНК (фрагменты $28 \mathrm{~S}$ и $5.8 \mathrm{~S}+\mathrm{ITS} 2$ ) оказалось, что они совпадают с маритами Hemiurus levinseni (Digenea: Hemiuroidea: Hemiuridae). Мы предлагаем схему жизненного цикла H. levinseni, приводим описание спороцист и церкарий этого вида и сравниваем церкарий разных видов гемиуроидей. Также обсуждается положение рода Hemiurus в сем. Hemiuridae на основе молекулярных данных.

Как цитировать эту статью: Krupenko D.Yu., Gonchar A.G., Kremnev G.A., Uryadova A.A. 2020. On the life cycle of Hemiurus levinseni Odhner, 1905 (Digenea: Hemiuridae) // Invert. Zool. Vol.17. No.3. P.205-218. doi: 10.15298/invertzool.17.3.01

КЛЮЧЕВЫЕСЛОВА: жизненные циклы, Digenea, Hemiuroidea, Hemiuridae, церкарии, рДНК.

Paper is dedicated to the memory of A.A. Dobrovolsky.

Статья посвящена памяти А.А. Добровольского. 


\section{Introduction}

Exploring life cycle patterns is one of the major clues for understanding the evolution of the Digenea. It is particularly so for the superfamily Hemiuroidea Looss, 1899, as its representatives are found in both marine and freshwater environments (Hunninen, Cable, 1943; Madhavi, 1978; Stunkard, 1980; Goater et al., 1990) and possess different types of life cycles. Typical hemiuroidean life cycle includes three or four hosts (Cribb et al., 2003), though some species demonstrate a tendency towards progenesis (Kulachkova, 1972; Køie, 1979). This tendency probably led to the emergence of onehost cycles in several different lineages of the Hemiuroidea (Poulin, Cribb, 2002). The definitive hosts of the hemiuroideans are usually teleost fishes, with several exceptions (Gibson, 2002). Crustaceans (frequently — planktonic copepods) act as the second intermediate hosts and set up the route of infection through food webs towards the definitive host (Køie, 1979, 1989; Marcogliese, 1995). Another fascinating feature of the hemiuroideans is an extremely wide range of the first intermediate hosts. They comprise the Caenogastropoda (Madhavi, 1978; Køie, 1979; Stunkard, 1980; Køie, Gibson, 1991), Vetigastropoda (Køie, 1990a), Heterobranchia - both "opisthobranchs" (Hunninen, Cable, 1943; Køie, 1989, 1990b, 1991, 1992, 1995) and "pulmonates" (Goater et al., 1990); several species are also known from the Scaphopoda (Køie et al., 2002), and one from the Bivalvia (Wardle, 1975). Collecting more life cycle data will give an excellent opportunity to explore coevolution and host-switch processes within this group of the Digenea.

All known cercariae of the Hemiuroidea are of cystophorous type ${ }^{1}$ : their tail is highly modified to form a caudal cyst into which the cercarial body is withdrawn (Gibson, Bray, 1986). During the tail development, a delivery tube structure providing infection of the second intermediate host - is formed as an appendage on the caudal cyst. Later the delivery tube is re-

\footnotetext{
${ }^{1}$ Ptychogonomidae may be the only exception, but their systematic position is uncertain for now.
}

tracted into the caudal cyst. When copepod bites the caudal cyst with mandibles the delivery tube everts and injects cercarial body into the host haemocoel (Matthews, 1981a). In many hemiuroidean cercariae caudal cyst also bears a socalled excretory appendage of various shapes which can provide motility of the infective cercariae (Pelseneer, 1906; Chubrik, 1966; Køie, 1979, 1990b, 1992, 1995). The advent of cystophorous cercariae was crucial for the transmission strategy of the Hemiuroidea, thus its structure is another important character to analyze from the perspective of the hemiuroidean evolution.

One of the common hemiuroidean species in arctic-boreal waters is Hemiurus levinseni Odhner, 1905 (Hemiuridae) (Gibson, Bray, 1986; Hemmingsen, MacKenzie, 2001; Køie, 2009). It is the only species of this genus in the White Sea (Shulman, Shulman-Albova, 1953). The life cycle of $H$. levinseni remains unknown: cystophorous cercariae from Euspira pallida (Broderip et Sowerby, 1829) which were supposed to belong to H. levinseni (Køie, 1990c) later were shown to be some unidentified representative of the family Derogenidae (Køie, 1995, 2000). Heterobranch gastropods from the order Cephalaspidea should be considered when searching for the first intermediate host of $H$. levinseni as these molluscs are utilized by several other species of the family Hemiuridae (Køie, 1990b, 1991, 1992, 1995). In the White Sea these gastropods have never been examined for digeneans. As Cylichna alba (Brown, 1827) is the most abundant representative of the Cephalaspidea in shallow waters of the White Sea, we supposed it to be the most likely candidate for the first intermediate host of $H$. levinseni.

In this paper we describe daughter sporocysts and cystophorous cercariae found in $C$. alba which by molecular evidence match sexual adults of $H$. levinseni from fish. Thus, the life cycle for this species is outlined.

\section{Material and methods}

Hosts were sampled in the White Sea, Kandalaksha Bay, Keret Archipelago. Gastropods 
Cylichna alba were collected in the upper subtidal $(2-5 \mathrm{~m})$ near the island Vichennaya luda in June $(n=34)$ and August $(n=82) 2019$. Eight species of fish were collected near the islands Vichennaya luda, Malyi Gorelyi and Matrenin in summer 2018 and summer-autumn 2019. These were Atlantic cod Gadus morhua Linnaeus, 1758, navaga Eleginus nawaga (Walbaum, 1792), shorthorn sculpin Myoxocephalus scorpius (Linnaeus, 1758), herring Clupea pallasii Valenciennes, 1847, European flounder Platichthys flesus (Linnaeus, 1758), Arctic flounder Liopsetta glacialis (Pallas, 1776), common dab Limanda limanda (Linnaeus, 1758), and wolffish Anarhichas lupus Linnaeus, 1758.

Hosts were dissected, tissues of C. alba were examined in seawater and guts of fish - in physiological solution $(0.9 \% \mathrm{NaCl})$. Adults of Hemiurus levinseni from fish were identified according to the keys in Gibson \& Bray (1979, 1986) also considering Bray \& Cribb (2005). Sporocysts and cercariae from C. alba and sexual adults of $H$. levinseni from fish were preserved in $96 \%$ ethanol for molecular analysis and preparation of whole mounts. Also, cercariae and daughter sporocysts from C. alba were fixed with $2.5 \%$ glutaraldehyde in seawater and with $4 \%$ paraformaldehyde in $0.01 \mathrm{M}$ phosphate buffered saline. The sexual adults of $H$. levinseni from fish were mounted in glycerol unstained to double-check the morphological identification and to make photographs. Glutaraldehyde-fixed cercariae and sporocysts had a better-preserved shape, so they were temporarily mounted to make photographs and line drawings. Photographs of the whole-mounted worms were made using a compound microscope Leica DM 2500 (Leica Microsystems) and a camera Nikon DS Fi1 with differential interference contrast microscopy (DIC). Measurements were made using Fiji software (Schindelin et al., 2012). All measurements are in micrometres. Measurements of daughter sporocysts are based on four young and four mature specimens, of pre-infective cercariae - on nine fixed specimens, of infective cercariae - on 21 fixed specimens; not all specimens contributed a data point to all metrical variables. For SEM glutaraldehyde-fixed cercariae were dehydrated in ethanol and acetone, dried in critical point dryer, coated with platinum, and examined with Quanta 250 at $15 \mathrm{kV}$. Additional information on the cercariae inner structure was obtained by means of TRITC-phalloidin labelling and confocal laser scanning microscopy (CLSM) following protocol previously described by Krupenko \& Gonchar (2017); this way f-actin in the flame-cell collars and musculature in the distal part of excretory vesicle were visualized.

For molecular analysis we used sporocysts from three different specimens of C. alba and parts of the sexual adults of $H$. levinseni from different fish species (Table 1). They were taken from 96\% ethanol, dried completely, and DNA was extracted from each of them separately by incubation in $200 \mu \mathrm{L} 5 \%$ Chelex ${ }^{\circledR} 100$ resin (Bio-Rad, USA) solution with $0.2 \mathrm{mg} / \mathrm{mL}$ proteinase $\mathrm{K}$ at $56{ }^{\circ} \mathrm{C}$ overnight; 8 min at $90{ }^{\circ} \mathrm{C}$; and centrifugation at $16,000 \mathrm{~g}$ for $10 \mathrm{~min}$. Supernatant containing DNA was then transferred to a new tube and stored at $-20{ }^{\circ} \mathrm{C}$. To amplify a 500 base pairs (bp) long D2 domain of the 28S rRNA gene (LSU) we used a forward C2'B (GAAAAGTACTTTGRARAGAGA, Bayssade-Dufour et al., 2006) and a reverse D2 primer (TCCGTGTTTCAAGACGGG, Vân Le et al., 1993) with the following thermocycling conditions: initial denaturation for $5 \mathrm{~min}$ at $95^{\circ} \mathrm{C}$; 35 cycles with $30 \mathrm{~s}$ at $95^{\circ} \mathrm{C}, 30 \mathrm{~s}$ at $53^{\circ} \mathrm{C}$ and $1 \mathrm{~min}$ at $72{ }^{\circ} \mathrm{C}$; final elongation for 10 min at $72{ }^{\circ} \mathrm{C}$; and cooling to $4{ }^{\circ} \mathrm{C}$. To amplify a $\sim 1200$ bp long D1-D3 LSU domains region we used a digl2 forward (AAGCATATCACTAAGCGG, Tkach et al., 1999) and a 1500R reverse primer(GCTATCCTGAGGGAAACTTCG, Olson et al., 2003) with the following thermocycling conditions: $3 \mathrm{~min}$ at $95{ }^{\circ} \mathrm{C} ; 40$ cycles with 30 s at $95^{\circ} \mathrm{C}, 30 \mathrm{~s}$ at $54^{\circ} \mathrm{C}$ and 2 min at $72{ }^{\circ} \mathrm{C} ; 10 \mathrm{~min}$ at $72{ }^{\circ} \mathrm{C}$; and cooling to $4{ }^{\circ} \mathrm{C}$. To amplify a $\sim 600 \mathrm{bp}$ fragment comprising 5.8S+ITS2, we used a forward 3S (GGTACCGGTTCACGTGGCTAGTG) and a reverse ITS2.2 primer (CCTGGTTAGTTTCTTTTCCTCCGC) (Morgan, Blair, 1995) with thermocycling conditions described by Shimazu et al. (2014). Amplifications were performed in 
Table 1. Isolates, their origin, and GenBank accession numbers for sequences.

Таблица 1. Изоляты, их происхождение и номера последовательностей в базе данных GenBank.

\begin{tabular}{|l|l|l|l|c|}
\hline & & & \multicolumn{2}{|c|}{ GenBank accession number } \\
\hline ID & Stage & Host species & 28S rDNA & 5.8S rDNA+ITS2 \\
\hline 30.48.c & $\begin{array}{l}\text { Sporocysts } \\
\text { and cercariae }\end{array}$ & $\begin{array}{l}\text { Cylichna alba (Brown, } \\
1827)\end{array}$ & MN962990 & MT644465 \\
\hline 294.48.c & $\begin{array}{l}\text { Sporocysts } \\
\text { and cercariae }\end{array}$ & $\begin{array}{l}\text { Cylichna alba (Brown, } \\
1827)\end{array}$ & MN962991 & MT644463 \\
\hline 295.48.c & $\begin{array}{l}\text { Sporocysts } \\
\text { and cercariae }\end{array}$ & $\begin{array}{l}\text { Cylichna alba (Brown, } \\
\text { 1827) }\end{array}$ & MN962992 & MT644466 \\
\hline 2.45.c & Sexual adult & $\begin{array}{l}\text { Liopsetta glacialis (Pallas, } \\
\text { 1776) }\end{array}$ & MN962993 & MT644462 \\
\hline 4.45.c & Sexual adult & $\begin{array}{l}\text { Platichthys flesus } \\
\text { (Linnaeus, 1758) }\end{array}$ & MN962994 & MT644470 \\
\hline 10.45.c & Sexual adult & $\begin{array}{l}\text { Eleginus nawaga } \\
\text { (Walbaum, 1792) }\end{array}$ & MN962995 & MT644471 \\
\hline 305.48.c & Sexual adult & $\begin{array}{l}\text { Myoxocephalus scorpius } \\
\text { (Linnaeus, 1758) }\end{array}$ & MN962996 & MT644464 \\
\hline 284.48.c & Sexual adult & $\begin{array}{l}\text { Gadus morhua } \text { Linnaeus, } \\
\text { 1758 }\end{array}$ & MN962997 & MT644467 \\
\hline 1.49.c & Sexual adult & $\begin{array}{l}\text { Gadus morhua } \text { Linnaeus, } \\
\text { 1758 }\end{array}$ & MN962998 & MT644469 \\
\hline 3.49.c & Sexual adult & $\begin{array}{l}\text { Myoxocephalus scorpius } \\
\text { (Linnaeus, 1758) }\end{array}$ & MN962999 & MT644468 \\
\hline
\end{tabular}

$25 \mu \mathrm{L}$ reaction mixtures containing $16 \mu \mathrm{L}$ Milli$\mathrm{Q}{ }^{\circledR}$ water, $5 \mu \mathrm{L}$ ScreenMix-HS reaction mix (Evrogen, Russia), $1 \mu \mathrm{L}$ of both $\mathrm{F}$ and R primers, and $2 \mu \mathrm{L}$ DNA template. PCR products were visualized on a $1 \%$ agarose gel with SYBR ${ }^{\circledR}$ Green (Invitrogen, MA, USA), and sequenced on an ABI PRISM 3500xl (Applied Biosystems, MA, USA) with PCR primers. Sequence data were processed using Geneious ${ }^{\circledR}$ 11.1.5 (https://www.geneious.com). To annotate the ITS region, we used the sequence of Echinostoma revolutum (U58102; Morgan, Blair, 1995) as a reference. Dataset for phylogenetic reconstructions was based on that from Sokolov et al. (2019) and included part of the taxa from the Clade B: Hemiuridae, Lecithasteridae and Merlucciotrema praeclarum (Manter, 1934) Yamaguti, 1971. Among these sequences the one named "Hemiurus luehei Odhner, 1905" (MH628316) appeared to be misidentified in the original paper (personal communication of one of the coauthors I.I. Gordeev); that is why we will use this species name in quotation marks ${ }^{2}$. Additionally our dataset included Hemiurus appendiculatus (Rudolphi, 1802) Looss, 1899 (KR349118 and KR349121) sequences from Bao et al., 2015. Bunocotyle progenetica (Markowski, 1936) Chabaud et Buttner, 1959 (DQ354365) (family Bunocotylidae) from Pankov et al. (2006) served as an outgroup. Phylogeny was inferred with maximum likelihood (ML) and Bayesian inference (BI) approaches. The best substitution model was estimated as GTR $+\mathrm{G}$ using jModelTest 2.1.10 (Guindon, Gascuel, 2003; Darriba et al., 2012). The ML tree was constructed in PhyML

${ }^{2}$ According to the personal communication of Dr Ilya I. Gordeev, the authors had at their disposal a fragment of a trematode body with a label "Hemiurus luehei ex Ophidion rochei, stomach; the Black Sea near Sevastopol" provided to them by the colleagues from the A.O. Kovalevsky Institute of Biology of the Southern Seas (Sevastopol). The researchers were not able to verify the species affiliation of this partial specimen. Dr Gordeev suggests that in fact this fragment belongs to a representative of the genus Lecithochirium. 

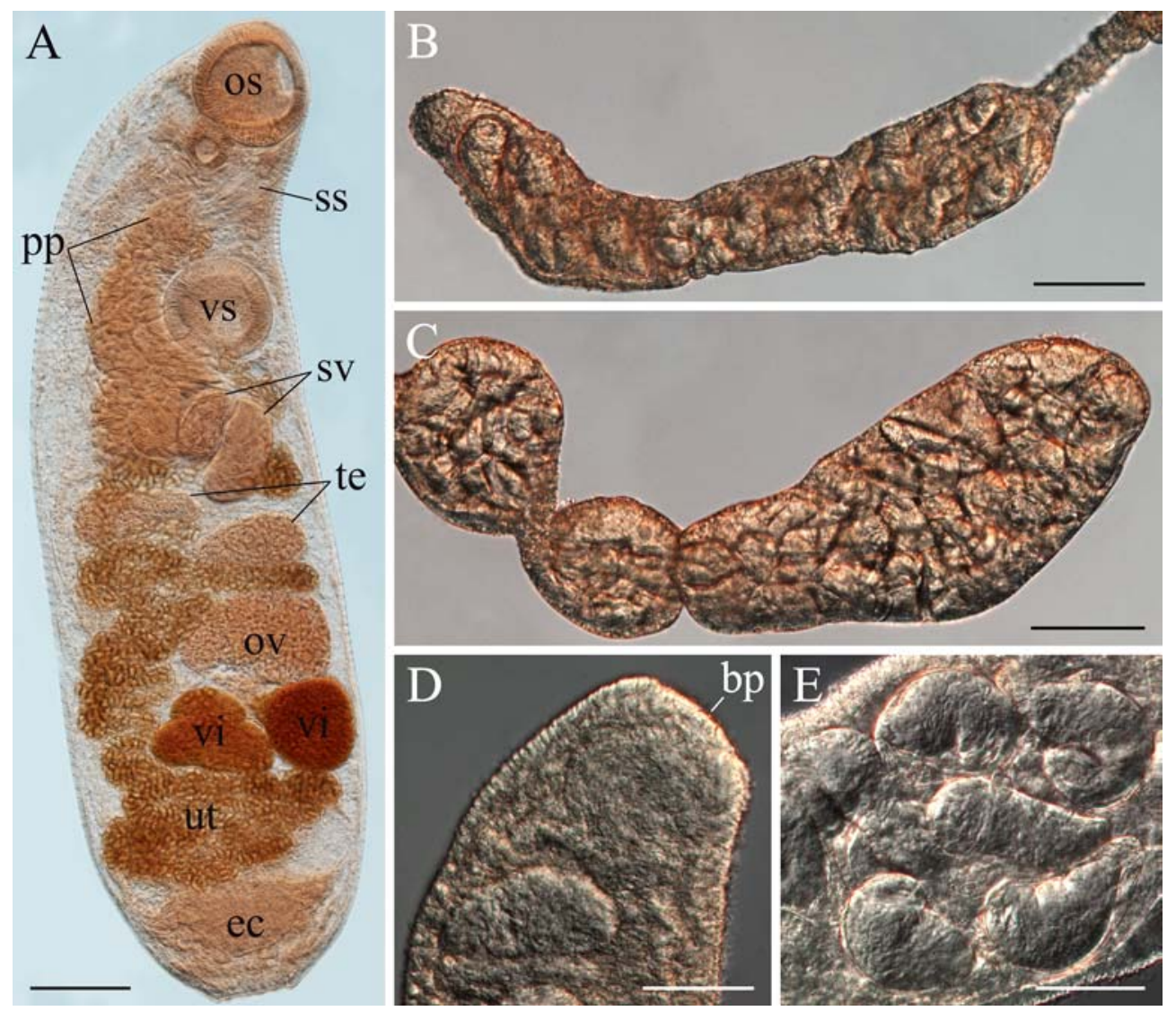

Fig. 1. Stages of Hemiurus levinseni life cycle (DIC). A — sexual adult; B-E - daughter sporocyst; B anterior part of body; $\mathrm{C}$ - posterior part of body; D - anterior end with birth pore; E - infective cercariae inside sporocyst.

Abbreviations: bp — birth pore; ec — ecsoma; os — oral sucker; ov — ovary; pp — pars prostatica; ss — sinus-sac; sv — seminal vesicle; te - testes; ut - uterus; vi - vitellarium; vs — ventral sucker. Scale bars: A-C - $100 \mu \mathrm{m}$; D, $\mathrm{E}-50 \mu \mathrm{m}$.

Рис. 1. Стадии жизненного цикла Hemiurus levinseni (DIC). A - марита; B-E - дочерние спороцисты; В — передняя часть тела; C — задняя часть тела; D - передний конец тела с родильной порой; $\mathrm{E}$ - инвазионные церкарии внутри спороцисты.

Обозначения: $\mathrm{bp}$ - родильная пора; ec - эксома; os - ротовая присоска; ov — яичник; pp — простатическая часть; ss - бурса синуса; sv — семенной пузырёк; te — семенники; ut — матка; vi — желточники; vs — брюшная присоска. Масштаб: А-C - 100 мкм; D, E - 50 мкм.

3.0 (Guindon et al., 2010) with 1000 bootstrap replicates. The BI tree was constructed in MrBayes v.3.2.6 with 10000000 generations (Huelsenbeck, Ronquist, 2001; Ronquist, Huelsenbeck, 2003).

\section{Results}

We found sexual adults of Hemiurus levinseni (Fig. 1A) in Atlantic cod, navaga, shorthorn sculpin, herring, common dab, European flounder, and Arctic flounder.

Of 34 Cylichna alba collected in June 2019 one (3\%) was infected with sporocysts containing infective cystophorous cercariae (Fig. 1BE). Of 82 C. alba collected in August 2019 two $(2 \%)$ were infected with similar sporocysts though these contained underdeveloped cystophorous cercariae. 


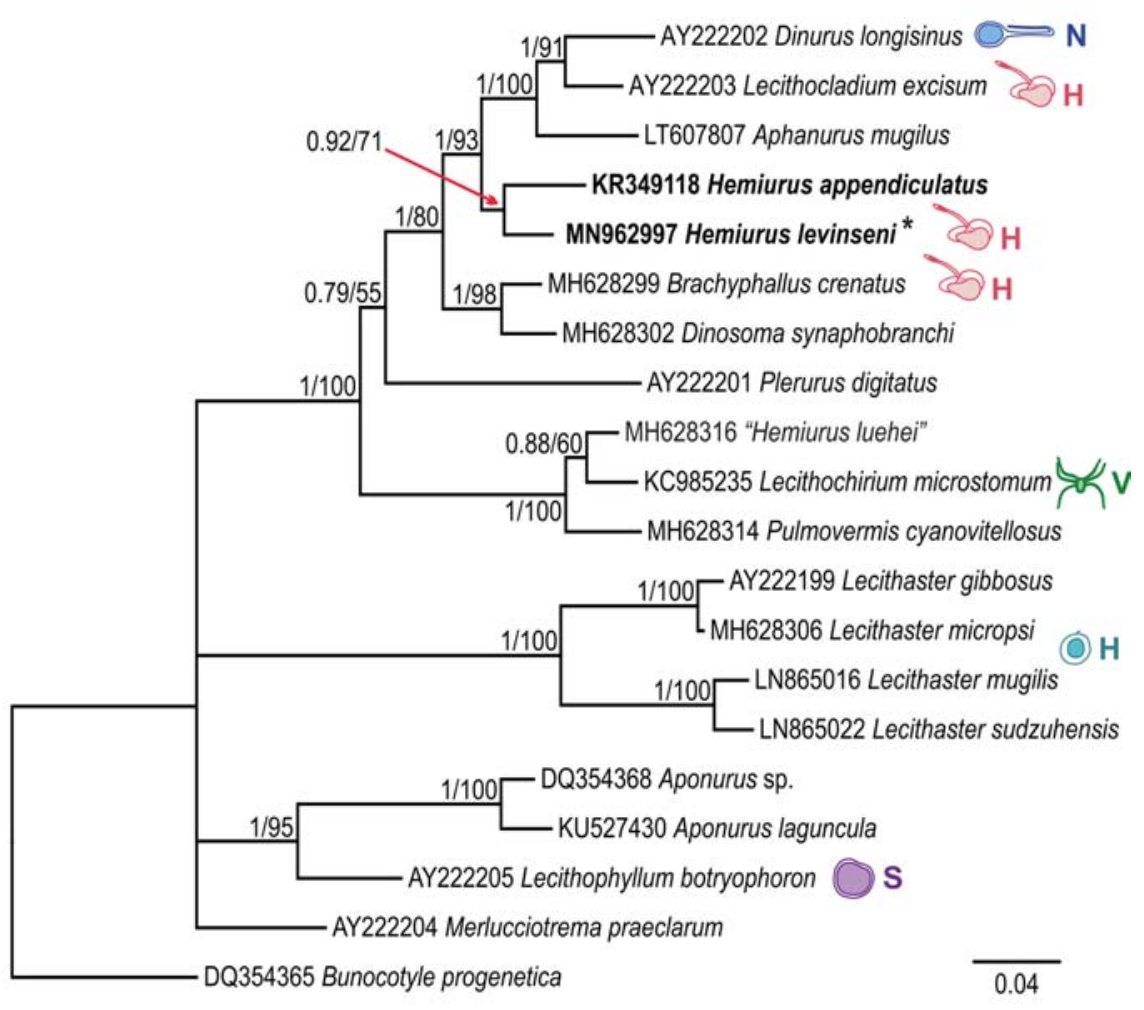

Fig. 2. Phylogenetic tree highlighting the position of Hemiurus based on 28S rDNA sequences, built with Bayesian inference (BI). Posterior probabilities are printed at nodes, supplemented with bootstrap support values computed for the same nodes with the ML method (BI/ML). Species names are preceded by the GenBank accession numbers. Asterisk indicates the sequence obtained in this study. Representatives of the genus Hemiurus are in bold (MH628316 does not belong to this genus (see "Material and Methods")). Available information on cercariae morphology (icons, see text for details) and taxonomic affinities of the first intermediate hosts ( $\mathrm{H}$ - Heterobranchia, $\mathrm{N}$ - Neogastropoda, V - Vetigastropoda, S - Scaphopoda) is mapped on the tree next to relevant genera (except for Dinurus longisinus, where data on the representative of a closely related genus (Tubulovesicula pinguis) are mapped). Scale bar shows substitutions per site. Рис. 2. Филогенетическое древо, построенное методом Байеса (BI) на основе последовательностей $28 \mathrm{~S}$ рДНК и показывающее положение рода Hemiurus. В узлах отмечены апостериорные вероятности и значения бутстреп-поддержки (ML), полученные для того же набора данных методом максимального правдоподобия (BI/ML). Названия видов приведены с номерами из GenBank. Звёздочкой отмечена последовательность, полученная в этом исследовании. Представители рода Hemiurus выделены полужирным шрифтом (МН628316 не относится к данному роду (см. «Материал и методы»)). Имеющиеся данные по морфологии церкарий (пояснения значков см. в тексте) и таксономической принадлежности первых промежуточных хозяев $(\mathrm{H}-$ Heterobranchia, $\mathrm{N}-\mathrm{Neo-}$ gastropoda, V - Vetigastropoda, S - Scaphopoda) отмечены на дереве рядом с соответствующими родами (кроме Dinurus longisinus, где использованы данные по представителю близкого рода Tubulovesicula pinguis). Масштабная линейка показывает количество замен на одну позицию последовательности.

\section{Molecular data}

We obtained LSU sequences for each sample: four D2 fragments (490-511 bp long) and six D1-D3 fragments (1167-1168 bp long). Pairwise identity of these sequences was $99.9 \%$, with two ambiguities and two possible substitutions: G/A in 305.48.c and 284.48.c (position 438) and $A / G$ in 294.48.c and 295.48.c (position 697). The closest BLAST hit was Hemiurus appendiculatus, a congener that differed from 


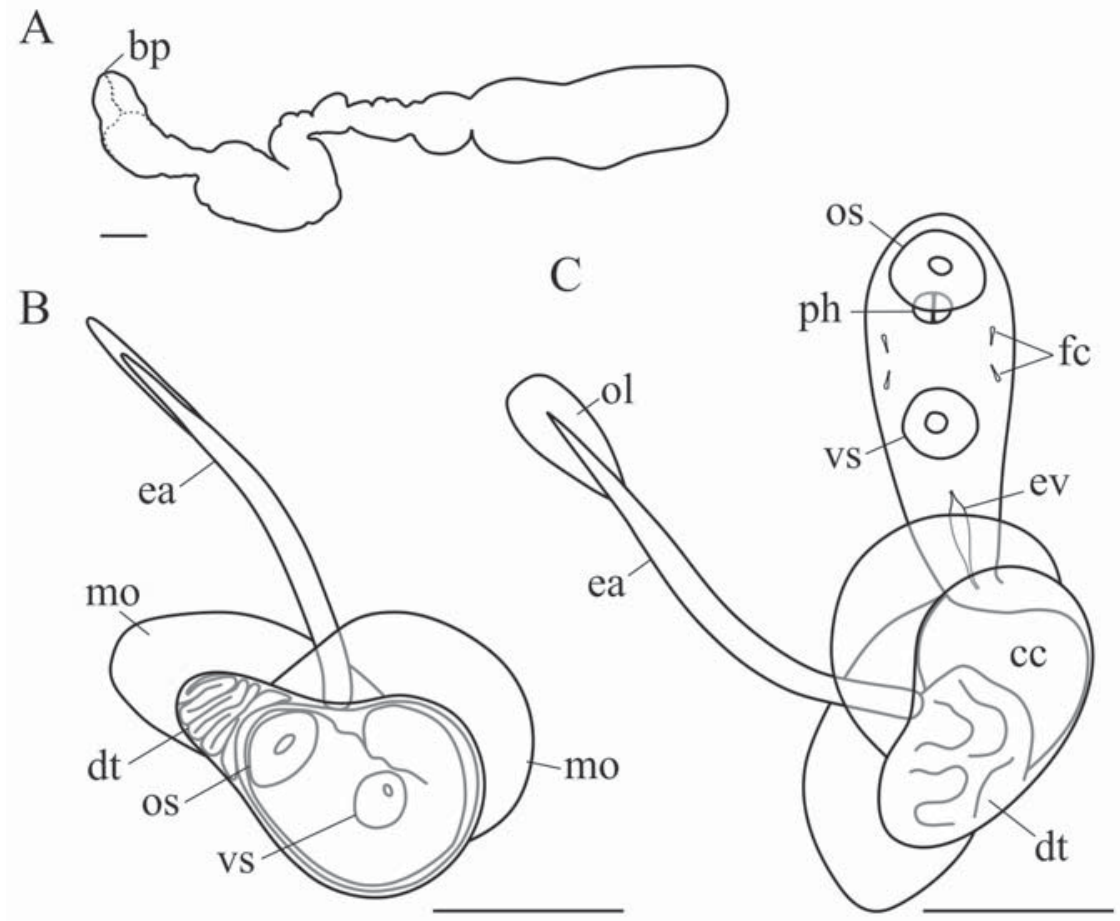

Fig. 3. Intramolluscan stages of Hemiurus levinseni life cycle. A - daughter sporocyst; B - infective cercaria; $\mathrm{C}$ - pre-infective cercaria.

Abbreviations: bp — birth pore; cc — caudal cyst; $\mathrm{dt}$ — delivery tube; ea — excretory appendage; ev — excretory vesicle (distal part); fc — flame cells; mo - membranous outgrowths; ol — oar-shaped lobe; os — oral sucker; ph — pharynx; vs - ventral sucker. Scale bars: A $-100 \mu \mathrm{m} ; \mathrm{B}, \mathrm{C}-50 \mu \mathrm{m}$.

Рис. 3. Стадии жизненного цикла Hemiurus levinseni внутри первого промежуточного хозяина. А дочерняя спороциста; В - инвазионная церкария; C - преинвазионная церкария.

Обозначения: $\mathrm{bp}-$ родильная пора; $\mathrm{cc}-$ хвостовая капсула; $\mathrm{dt}-$ извергательная трубка; еа - хвостовой придаток; ev — мочевой пузырёк (дистальная часть); fc — циртоциты; mо — гребневидные выросты капсулы; ol — веслообразная лопасть; os — ротовая присоска; ph — глотка; vs - брюшная присоска. Масштаб: A - 100 мкм; В, С-50 мкм.

our sequences by $47-48$ nucleotide substitutions (907 bp alignment). Two isolates of $H$. appendiculatus from Alosa alosa (KR349118) and A. fallax (KR349121) in western Spain had identical sequences.

We also obtained 612-667 bp sequences of the ITS region for each sample. They covered the partial 5.8S rDNA (140 bp), the complete ITS2 (451 bp) and 21-76 bp corresponding to the start of the $28 \mathrm{~S}$ rDNA. The alignment trimmed to the shortest sequence was $612 \mathrm{bp}$ long and had a $99.9 \%$ pairwise identity. Single ambiguous positions were found in sequences from three isolates: 1.49.c, 284.48.c and 3.49.c.
Sequence from isolate 295.48.c had two substitutions: T/C in the position 295 and $\mathrm{A} / \mathrm{T}$ in the position 513. Among the Hemiuroidea, replicate sequences of the ITS region are available for two species of the Lecithasteridae. Sequences from three isolates of Hysterolecithoides epinepheli were identical. In Lecithaster confusus, the pairwise identity was $99 \%$ among 7 isolates for a $643 \mathrm{bp}$ alignment.

Phylogenetic trees inferred with ML and BI revealed congruent topology. The Bayesian tree is presented in Figure 2; the posterior probabilities are supplemented with the support values computed for the same nodes with the ML 
method. Our results were generally consistent with data from Sokolov et al. (2019) but had lower resolution. The composition of the Hemiuridae and relationships within this family on our tree agree with previous findings. Our sample of $H$. levinseni groups together with $H$. appendiculatus, but not with " $H$. luehei" (MH628316) apparently due to the misidentification of this sample in Sokolov et al. (2019) (see "Material and Methods").

\section{Sporocysts}

Each infected C. alba contained 30-40 daughter sporocysts. Sporocysts filled with cercariae at various stages of development, $\sim 1500$ long, 83-199 (126) wide, white, with constrictions (Fig. 1B-E, 3A). Only the specimen collected in June 2019 contained fully formed cercariae with body withdrawn into caudal cyst. Young daughter sporocysts containing only early embryos of cercariae 616-754 (690) long, 46-92 (71) wide, constrictions not prominent.

\section{Cercariae}

Early developmental stages of the cercariae are represented by germinal balls which later become divided into two parts: the cercarial body and the tail primordium. Next, the latter is divided into three lobes: the posterior one will become the motile excretory appendage, and two lateral lobes - the delivery tube and the caudal cyst itself (Fig. 4A). Due to asymmetrical growth of the caudal cyst, the base of the motile appendage moves to a side, and the base of the delivery tube primordium submerges into the cyst (Fig. 4B-F). The delivery tube develops as a column of cells, later their nuclei degenerate, the tube becomes hollow and withdraws into the cyst.

Pre-infective cercariae have the delivery tube coiled inside the cyst, but the cercarial body is still outside (Fig. 3C, 4G). Body 99-134 (110) long, 31-38 (35) wide. Oral sucker 19-22 × 21$23(21 \times 22)$, ventral sucker $16-19 \times 18-21(18$ $\times 20)$, pharynx $8-10 \times 9-12(9 \times 11)$. Excretory formula $2(1+1)=4$.

The caudal cyst of infective cercariae is pear-shaped, with one side concave, 80-86 (83) long, 49-54 (52) wide (Fig. 3B, 4H, 5A). Its surface is finely folded. The aperture is located at the wide part of the cyst, near the concave surface (Fig. 5B). Two asymmetrical membranous outgrowths go along the concave surface. The motile excretory appendage is attached in the middle of the concave surface, between the outgrowths (Fig. 5A). It is 124-150 (134) long, the flattened oar-shaped distal part is $42-52$ (48) long, 14-22 (19) wide, serrated apically (Fig. 5C). The stem is oval in cross-section, 10$11 \times 6-7(11 \times 6)$, annulated (Fig. 5A, C).

In infective cercariae the narrow part of the caudal cyst is occupied by the tightly packed delivery tube. The cercarial body is withdrawn into the cyst and already detached from it; it lies with the anterior end close to the delivery tube.

\section{Discussion}

Using morphological and molecular data, we have partially elucidated the life cycle of Hemiurus levinseni. The identification of this species was based on the morphology of the sexual adults: all of them comply with the diagnosis of $H$. levinseni. It is also the only species of Hemiurus previously found in the White Sea (Shulman, Shulman-Albova, 1953), but three other species occur in the north-east Atlantic: Hemiurus communis Odhner, 1905, H. appendiculatus, and $H$. luehei. H. levinseni is readily distinguished through morphology from all of them. The most apparent character is the sucker ratio which is $1:<1.1$ in $H$. levinseni and 1 : $>1.43$ in the other species (Gibson, Bray, 1986; Bray, Cribb, 2005). To match the sexual adults of $H$. levinsen $i$ and its intramolluscan stages, we used DNA sequencing.

Sequences of the partial 28S rDNA and 5.8S rDNA+ITS2 suggest that all our samples belong to a single species, and thus constitute the life cycle stages of $H$. levinseni. The only possible concern is that both fragments showed intraspecific variability, although very low. We believe that this is not sufficient to question the conspecificity of our material at this point. We have sequenced ten replicates for the species, and larger sample size increases the chances to 

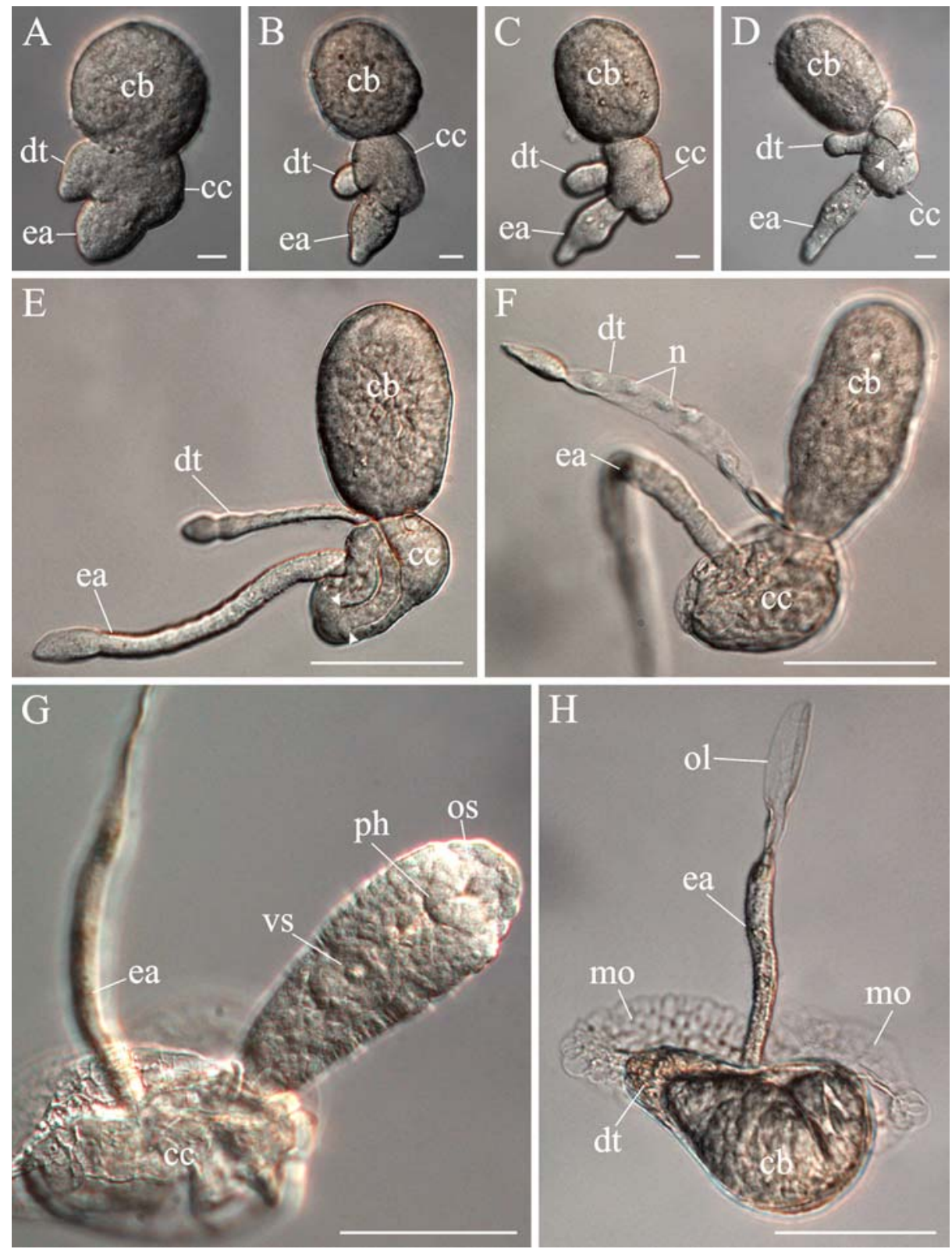

Fig. 4. Development of Hemiurus levinseni cercariae (DIC). A-F - sequential stages of cercariae development, arrowheads on D and $\mathrm{E}$ mark the base of delivery tube; $\mathrm{G}$ - pre-infective cercaria; $\mathrm{H}-$ infective cercaria.

Abbreviations: $\mathrm{cb}$ - cercarial body; cc - caudal cyst; $\mathrm{dt}$ - delivery tube; ea - excretory appendage; mo membranous outgrowths; $\mathrm{n}$ — nuclei; ol — oar-shaped lobe; os — oral sucker; ph — pharynx; vs — ventral sucker. Scale bars: A-D $-10 \mu \mathrm{m} ; \mathrm{E}-\mathrm{H}-50 \mu \mathrm{m}$.

Рис. 4. Развитие церкарий Hemiurus levinseni (DIC). А-F - последовательные стадии развития церкарий, стрелками на D и $\mathrm{E}$ отмечено основание извергательной трубки; $\mathrm{G}$ - преинвазионная церкария; $\mathrm{H}$ - инвазионная церкария.

Обозначения: $\mathrm{cb}$ - тело церкарии; $\mathrm{cc}-$ хвостовая капсула; $\mathrm{dt}-$ извергательная трубка; еа - хвостовой придаток; mo - гребневидные выросты капсулы; $\mathrm{n}$ - ядра; ol - веслообразная лопасть; os - ротовая присоска; $\mathrm{ph}$ - глотка; vs - брюшная присоска. Масштаб: А-D - 10 мкм; E-H - 50 мкм. 

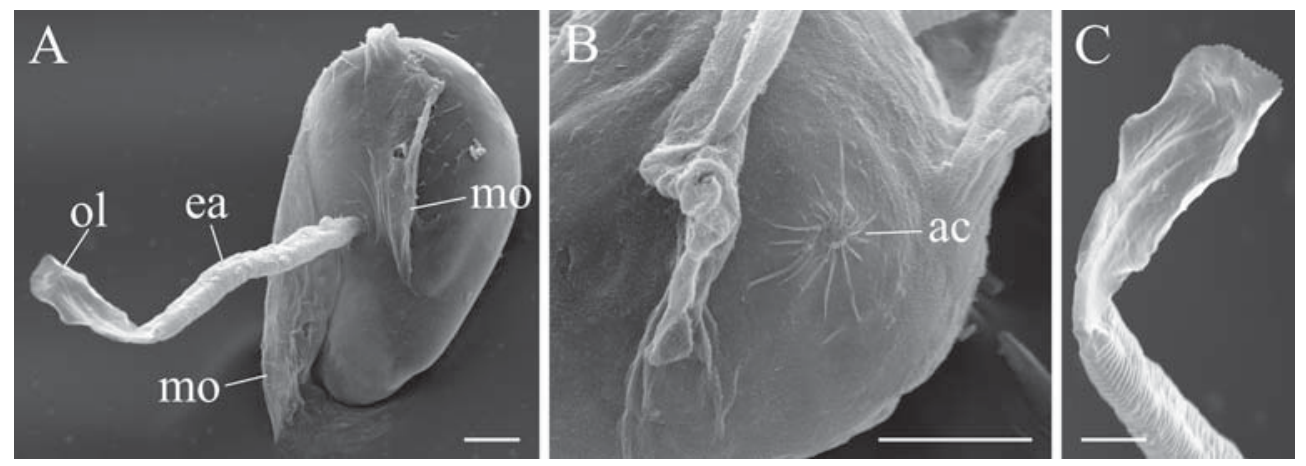

Fig. 5. Infective cercariae of Hemiurus levinseni (SEM). A — general view; B — aperture of caudal cyst; $\mathrm{C}$ - oar-shaped lobe on excretory appendage.

Abbreviations: ac - aperture of caudal cyst; ea - excretory appendage; mo - membranous outgrowths; ol - oarshaped lobe. Scale bars: A, B $-10 \mu \mathrm{m} ; \mathrm{C}-5 \mu \mathrm{m}$.

Рис. 5. Инвазионные церкарии Hemiurus levinseni (SEM). А - общий вид; В - отверстие хвостовой капсулы; C - веслообразная лопасть на хвостовом придатке.

Обозначения: ac - отверстие хвостовой капсулы; еа - хвостовой придаток; то - гребневидные выросты капсулы; ol - веслообразная лопасть. Масштаб: А, В - 10 мкм; С - 5 мкм.

detect intraspecific variability. Also, this is not a unique case: for example, there is variation within another hemiuroidean Lecithaster confusus (Atopkin et al., 2018). Importantly, the few detected substitutions and ambiguities in the 28S rDNA and in the ITS 2 are not consistent with each other. The reasons for the genetic variation that we observed within $H$. levinseni may get clarified in future.

In the White Sea two types of cystophorous cercariae have been described from the first intermediate hosts so far (Chubrik, 1966). The cercariae from Cryptonatica affinis (Gmelin, 1791) were proposed to belong to Derogenes varicus (Müller, 1784) Looss, 1901 and Lecithaster sp. (Chubrik, 1966; Timofeeva, 1976; Køie, 1979). Meanwhile, it is not $D$. varicus or Lecithaster sp. but two species of the family Hemiuridae (Hemiurus levinseni and Brachyphallus crenatus (Rudolphi, 1802) Odhner, 1905) which demonstrate the highest intensity of fish infection comparing to the other hemiuroideans in the White Sea (Shulman, ShulmanAlbova, 1953). Thus, the knowledge of their life cycles is important to estimate the impact of digeneans on the White Sea communities. The life cycle of $B$. crenatus was established by M. Køie (1992), whereas data on H. levinseni in intermediate hosts are fragmentary. Metacercariae of $H$. levinseni were recovered from chaetognaths Parasagitta elegans (Verrill, 1873 ) in the White Sea (Kulachkova, 1972) and in the Gulf of Saint Lawrence (Weinstein, 1966, 1967). In chaetognaths many metacercariae become sexually mature and produce eggs (Kulachkova, 1972). As H. levinseni is the only species of this genus reported from the White Sea, the records of Walter et al. (1979) on Hemiurus sp. metacercariae from several copepod species probably also refer to $H$. levinseni.

Based on the previous data and our results, the life cycle of $H$. levinseni proceeds as follows. The gastropods Cylichna alba serve as first intermediate hosts; daughter sporocysts producing cystophorous cercariae develop in their visceral mass. After emergence, cystophorous cercariae should be grabbed by planktonic copepods, which become infected by means of the delivery tube injection mechanism. Metacercariae develop in the haemocoel of the copepods. Chaetognaths probably acquire metacercariae by ingesting copepods. Fishes get infected by feeding on copepods, chaetognaths, or smaller fish. The sexual maturation of metacercariae may occur both in fishes and chaetognaths. Therefore, the life cycle of $H$. levinseni in 
outline is similar to those of $H$. luehei and $H$. communis (Køie, 1990b, 1995). However, the first intermediate hosts highlight the distinctness of our material from $H$. luehei and $H$. communis: all of them belong to the order Cephalaspidea, but the superfamilies (Philinoidea and Bulloidea) are different from what we have shown for $H$. levinseni (Cylichnoidea).

The early development of cystophorous cercariae is quite uniform in all the cases studied (Hunninen, Cable, 1943; Matthews, 1981b; Køie, Gibson, 1991; etc.). In H. levinseni it goes almost the same way as previously described for H. communis (Køie, 1995). The main difference is that cercariae of $H$. communis become infective shortly after emergence from the sporocyst when the cercarial body retracts into the caudal cyst (Køie, 1995), while we found infective cercariae inside the sporocysts of $H$. levinseni. The body size in pre-infective cercariae and the size of the caudal cyst of $H$. levinseni are similar to H. luehei and H. communis (Køie, 1990b, 1995). However, the motile appendage of $H$. levinseni is substantially shorter than those of $H$. luehei and H. communis. Unfortunately, we did not have a chance to observe eversion of the delivery tube in infective cercariae of $H$. levinseni, thus the number and shape of extensions on the fully formed delivery tube - one of the characters Køie (1995) used to differentiate cercariae of Hemiurus - is unknown.

In our phylogenetic tree $H$. levinseni forms a clade with $H$. appendiculatus, the type species of the genus. The position of the genus Hemiurus on our LSU-based tree $(H$. levinseni $+H$. appendiculatus clade) together with genera Dinurus and Lecithocladium is the same as on the 18S rDNA (SSU)-based trees in Pankov et al., 2006 (which included H. communis) and Bao et al., 2015 (which included H. communis and $H$. appendiculatus). Erroneous labeling of MH628316 (Sokolov et al., 2019) as "H. luehei" (see "Material and Methods") explains its grouping with Lecithochirium and Pulmovermis. Taking this into account, we do not consider $H$. luehei in the following discussion on the life cycles.

All the available data on the taxonomic affinity of the first intermediate host and cercar- iae morphology for the hemiuroideans included in our phylogenetic analysis are depicted in Figure 2. This information refers to exact genera except for Dinurus longisinus Looss, 1907 here we used data on a representative of a closely related genus (according to Gibson, 2002) Tubulovesicula pinguis (Linton, 1940) Manter, 1947. The pattern shows that both the first intermediate hosts (ord. Cephalaspidea) and the morphology of cystophorous cercariae (pyriform caudal cyst with two membranous outgrowths, motile excretory appendage with oar-shaped distal part) bring together Hemiurus, Brachyphallus crenatus and Lecithocladium excisum (Rudolphi, 1819) Lühe, 1901 (Køie, 1990b, 1991, 1992, 1995). Other studied hemiurids and their close relatives lecithasterids have immotile cercariae which lose excretory appendage during development (Hunninen, Cable, 1943; Stunkard, 1980; Matthews, Matthews, 1988; Køie, 1989; Køie, 1990a; Køie et al., 2002). However, all of them are quite different in morphology. To discuss which state is plesiomorphic, a broader context is needed.

Among the rest of the taxa from Clade B of Sokolov et al. (2019), the Bunocotylidae have a slightly motile caudal appendage (Chabaud, Buttner, 1954) and cercariae of the Isoparorchiidae are immotile (Ito, 1953; Shimazu et al., 2014). Outside Clade B of Sokolov et al. (2019) there are many taxa with unknown cercariae (Hirudinellidae, Didymozoidae, Gonocercidae, Accacoeliidae). Only for the Derogenidae cercariae are described: both immotile (Goater et al., 1990) and ones which possess motile excretory appendage, though not with an oar-shaped lobe, but furcate (Køie, 1979). This makes us suppose that the loss of an excretory appendage is probably a secondary event which occurred in the evolution of the Hemiuroidea multiple times: this would let them save limited energy resources and "make a bet" on the longevity of cercariae.

The first intermediate hosts of hemiurids and lecithasterids are of very different taxonomic affinity, including the Heterobranchia, Neogastropoda, Vetigastropoda, and even Scaphopoda. This makes one suspect several 
host-switch events in the evolution of their life cycles. We may also assume that heterobranchs from the order Cephalaspidea were parasitized by a common ancestor of a large branch of the Hemiuridae including Brachyphallus, Lecithocladium and Hemiurus. Evolution of life cycle traits within the Hemiuroidea will become more intelligible as new data on various genera of this diverse group appear.

\section{Acknowledgements}

This paper is dedicated to the memory of Dr. Andrej Dobrovolskij who inspired our interest in the Digenea.

The authors thank the Educational and Research Station "Belomorskaia" of Saint Petersburg University ( $\mathrm{SPbU}$ ) and the White Sea Biological Station "Kartesh" of the Zoological Institute, Russian Academy of Sciences (ZIN, RAS) for providing fieldwork resources. Sampling at the WSBS "Kartesh" was supported by research program of ZIN RAS (project No AAAA-A19-119020690109-2). The molecular studies were carried out in the research resource center "Molecular and Cell Technologies" of $\mathrm{SPbU}$, the SEM studies - in the "Taxon" Research Resource Center (http://www.ckp-rf.ru/ ckp/3038/) (ZIN, RAS), and the CLSM studies - in the Resource Center for Microscopy and Microanalysis of SPbU. We also acknowledge Sergei Bagrov and Dr. George Slyusarev for their help with sampling.

The reported study was funded by Russian Science Foundation, project No. 19-74-10029.

\section{References}

Atopkin D.M., Nakao M., Besprozvannykh V.V., Ha N.D., Nguyen H.V., Sasaki M. 2020. Morphological and molecular data for species of Lecithaster Lühe, 1901 and Hysterolecithoides Yamaguti, 1934 (Digenea: Lecithasteridae) from fish of East Asia and phylogenetic relationships within the Hemiuroidea Looss, 1899 // J. Helminthol. Vol.94. P. e14.

Bao M., Roura A., Mota M., Nachón D.J., Antunes C., Cobo F., MacKenzie K., Pascual S. 2015. Macroparasites of allis shad (Alosa alosa) and twaite shad (Alosa fallax) of the Western Iberian Peninsula Rivers: ecological, phylogenetic and zoonotic insights // Parasitol. Res. Vol.114. No.10. P.3721-3739.
Bayssade-Dufour C., Jouet D., Rudolfova J., Horák P., Ferté H. 2006. Seasonal morphological variations in bird schistosomes // Parasite. Vol.13. No.3. P.205214.

Bray R.A., Cribb T.H. 2005. Two new hemiurine species (Digenea: Hemiuridae) from Spratelloides robustus Ogilby (Clupeiformes: Clupeidae) off south-western Australia and records of Parahemiurus merus (Linton, 1910) from Australian and New Caledonian waters // Syst. Parasitol. Vol.60. No.3. P.197-203.

Chabaud A.G., Biguet J. 1954. Etude d'un Trématode Hémiuroïde à métacercaire progénétique. I. Développement chez le Mollusque. II. Infestation du Copépode. III. Développement chez le Copépode// Annales de parasitologie humaine et comparée. Vol.29. No.56. P.527-545.

Chubrik G.K. 1966. [Fauna and ecology of trematode larvae from molluscs in the Barents and White Seas] // Trudy Murmansk. morsk. biol. Inst. Vol.10. No.14. P.78-166 [in Russian].

Cribb T.H., Bray R.A., Olson P.D., Littlewood D.T.J. 2003. Life cycle evolution in the Digenea: a new perspective from phylogeny // Adv. Parasitol. Vol.54. P.197-254.

Darriba D., Taboada G.L., Doallo R., Posada D. 2012. jModelTest 2: more models, new heuristics and parallel computing // Nat. Methods. Vol.9. No.8. P. 772.

Gibson D.I. 2002. Superfamily Hemiuroidea Looss, 1899 // D.I. Gibson, A. Jones, R. Bray (eds.). Keys to the Trematoda. Vol.1. P.299-304.

Gibson D.I., Bray R.A. 1979. The Hemiuroidea: terminology, systematics and evolution // Bull. Br. Mus. Nat. Hist. (Zool.) Vol.36. No.2. P.35-146.

Gibson D.I., Bray R.A. 1986. The Hemiuridae (Digenea) of fishes from the north-east Atlantic // Bull. Br. Mus. Nat. Hist. (Zool.) Vol.51. P.1-125

Goater T.M., Browne C.L., Esch G.W. 1990. On the life history and functional morphology of Halipegus occidualis (Trematoda: Hemiuridae), with emphasis on the cystophorous cercaria stage // Int. J. Parasitol. Vol.20. No.7. P.923-934.

Guindon S., Gascuel O. 2003. A simple, fast and accurate method to estimate large phylogenies by maximumlikelihood // Syst. Biol. Vol.52. P.696-704.

Guindon S., Dufayard J.F., Lefort V., Anisimova M., Hordijk W., Gascuel O. 2010. New algorithms and methods to estimate maximum-likelihood phylogenies: assessing the performance of PhyML 3.0 // Syst. Biol. Vol.59. No.3. P.307-321.

Hemmingsen W., MacKenzie K. 2001. The parasite fauna of the Atlantic cod, Gadus morhua L. // Adv. Mar. Biol. Vol.40. P.1-80.

Huelsenbeck J.P., Ronquist F. 2001. MRBAYES: Bayesian inference of phylogeny // Bioinformatics. Vol.17. P.754-755.

Hunninen A.V., Cable R.M. 1943. The life history of Lecithaster confusus Odhner (Trematoda: Hemiuridae) // J. Parasitol. Vol.29. No.1. P.71-79.

Ito J. 1953. Two cystophorous cercariae, C. introverta Faust, 1942, and C. longicerca n. sp. From fresh water 
snail, Semisulcospira spp. in Japan, with a list of cystophorous cercariae// Jpn. J. Med. Sci. Biol. Vol.6. No.5. P.487-492.

Køie M. 1979. On the morphology and life-history of Derogenes varicus (Müller, 1784) Looss, 1901 (Trematoda, Hemiuridae) // Z. Parasitenkd.Vol.59. No.1. P.67-78.

Køie M. 1989. On the morphology and life history of Lecithaster gibbosus (Rudolphi, 1802) Lühe, 1901 (Digenea, Hemiuroidea) // Parasitol. Res. Vol.75. No.5. P.361-367.

Køie M. 1990a. Redescription of the cercaria of Lecithochirium rufoviride (Rudolphi, 1819) Lühe, 1901 (Digenea, Hemiuridae) (= Cercaria vaullegeardi Pelseneer, 1906) // Ophelia. Vol.31. No.2. P.85-95.

Køie M. 1990b. On the morphology and life-history of Hemiurus luehei Odhner, 1905 (Digenea: Hemiuridae) // J. Helminthol. Vol.64. No.3. P.193-202.

Køie M. 1990c. A new cystophorous cercaria in Lunatia pallida (Broderip \& Sowerby) (Naticidae): possibly the cercaria of Hemiurus levinseni Odhner, 1905 (Digenea, Hemiuridae) // Ophelia. Vol.31. No.2. P.77-84.

Køie M. 1991. Aspects of the morphology and life cycle of Lecithocladium excisum (Digenea, Hemiuridae), a parasite of Scomber spp. // Int. J. Parasitol. Vol.21. No.5. P.597-602.

Køie M. 1992. Life cycle and structure of the fish digenean Brachyphallus crenatus (Hemiuridae) // J. Parasitol. Vol.78. No.2. P.338-343.

Køie M. 1995. The life-cycle and biology of Hemiurus communis Odhner, 1905 (Digenea, Hemiuridae) // Parasite. Vol.2. P.195-202.

Køie M. 2000. Metazoan parasites of teleost fishes from Atlantic waters off the Faroe Islands // Ophelia. Vol.52. No.1. P.25-44.

Køie M. 2009. Boreogadus saida (Lepechin) (Gadidae): a review of its metazoan parasite fauna from Greenland, eastern Canada, Alaska and the Russian Arctic // Polar Biol. Vol.32. No.10. P.1399-1406.

Køie M., Gibson D.I. 1991. Aspects of the life-cycle of Magnibursatus caudofilamentosa (Reimer, 1971) Gibson \& Køie, 1991 (Digenea, Hemiuroidea, Derogenidae) // Ophelia. Vol.34. No.2. P.117-127.

Køie M., Karlsbakk E., Nylund A. 2002. A cystophorous cercaria and metacercaria in Antalis entalis (L.) (Mollusca, Scaphopoda) in Norwegian waters, the larval stage of Lecithophyllum botryophorum (Olsson, 1868) (Digenea, Lecithasteridae) // Sarsia. Vol.87. No.4. P.302-311.

Krupenko D., Gonchar A. 2017. Musculature arrangement and locomotion in notocotylid cercariae (Digenea: Notocotylidae) from mud snail Ecrobia ventrosa (Montagu, 1803) // Parasitol. Int. Vol.66. No.3. P.262-271.

Kulachkova V.G. 1972. [Helminths of Sagitta elegans Verrill from the White Sea] // Parazitologiia. Vol.6. No.3. P.297-304 [in Russian, with English summary].

Madhavi R. 1978. Life history of Genarchopsis goppo Ozaki, 1925 (Trematoda: Hemiuridae) from the freshwater fish Channa punctata // J. Helminthol. Vol.52. No.3. P.251-259.
Marcogliese D.J. 1995. The role of zooplankton in the transmission of helminth parasites to fish // Rev. Fish Biol. Fish. Vol.5. No.3. P.336-371.

Matthews B.F. 1981a. Cercaria vaullegeardi Pelseneer, 1906 (Digenea: Hemiuridae); the infection mechanism // Parasitology. Vol.83. No.3. P.587-593.

Matthews B.F. 1981b. Cercaria vaullegeardi Pelseneer, 1906 (Digenea: Hemiuridae); development and ultrastructure // Parasitology. Vol.83. No.3. P.575-586.

Matthews B.F., Matthews R.A. 1988. The ecsoma in Hemiuridae (Digenea: Hemiuroidea): tegumental structure and function in the mesocercaria and the metacercaria of Lecithochirium furcolabiatum (Jones, 1933) Dawes, 1947 // J. Helminthol. Vol.62. No.4. P.317-330.

Morgan J.A.T., Blair D. 1995. Nuclear rDNA ITS sequence variation in the trematode genus Echinosto$m a$ : an aid to establishing relationships within the 37collar-spine group // Parasitology. Vol.111. P.609615.

Olson P.D., Cribb T.H., Tkach V.V., Bray R.A., Littlewood D.T.J. 2003. Phylogeny and classification of the Digenea (Platyhelminthes: Trematoda) // Int. J. Parasitol. Vol.33. No.7. P.733-755.

Pankov P., Webster B.L., Blasco-Costa I., Gibson D.I., Littlewood D.T.J., Balbuena J.A., Kostadinova A. 2006. Robinia aurata n.g., n. sp. (Digenea: Hemiuridae) from the mugilid Liza aurata with a molecular confirmation of its position within the Hemiuroidea // Parasitology. Vol.133. No.2. P.217-227.

Pelseneer P. 1906. Trematodes parasites de mollusques marins // Bull. Biol. Fr. Bel. Vol.40 P.161-186.

Poulin R., Cribb T.H. 2002. Trematode life cycles: short is sweet? // Trends Parasitol. Vol.18. No.4. P.176-183.

Ronquist F., Huelsenbeck J.P. 2003. MRBAYES 3: Bayesian phylogenetic inference under mixed models // Bioinformatics. Vol.19. P.1572-1574.

Schindelin J., Arganda-Carreras I., Frise E. et al. 2012. Fiji: an open-source platform for biological-image analysis // Nat. Methods. Vol.9. P.676-682.

Shimazu T., Cribb T.H., Miller T.L., Urabe M., Van Ha N., Binh T.T., Shed'ko M.B. 2014. Revision of Isoparorchis Southwell, 1913 (Digenea, Hemiuroidea, Isoparorchiidae), parasites of the air bladder of freshwater catfishes: a molecular and morphological study // Bull. Natl. Mus. Nat. Sci. Ser. A. Vol.40. No.1. P.15-51.

Shulman S., Shulman-Albova R. 1953. [Parasites of Fishes of the White Sea]. Moskva-Leningrad: Izdatelstvo Akademia Nauk SSSR. 200 p. [In Russian]

Sokolov S.G., Atopkin D.M., Urabe M., Gordeev I.I. 2019. Phylogenetic analysis of the superfamily Hemiuroidea (Platyhelminthes, Neodermata: Trematoda) based on partial 28S rDNA sequences // Parasitology. Vol.146. No.5. P.596-603.

Stunkard H.W. 1980. The morphology, life history, and systematic relations of Tubulovesicula pinguis (Linton, 1940) Manter, 1947 (Trematoda: Hemiuridae) // Biol. Bull. Vol.159. No.3. P.737-751.

Timofeeva T.A. 1976. [Morphology and biology of cystophorous cercariae from the Barents Sea] // Parasi- 
tologiia. Vol.10. No.6. P.488-496 [in Russian, with English summary].

Tkach V., Grabda-Kazubska B., Pawlowski J., Swiderski Z. 1999. Molecular and morphological evidence for close phylogenetic affinities of the genera Macrodera, Leptophallus, Metaleptophallus and Paralepoderma [Digenea, Plagiorchiata] // Acta Parasitol. Vol.44. No.3. P.170-179.

Vân Le H.L., Lecointre G., Perasso R. 1993. A 28S rRNAbased phylogeny of the gnathostomes: first steps in the analysis of conflict and congruence with morphologically based cladograms // Mol. Phylogenet. Evol. Vol.2. No.1. P.31-51.

Walter E.D., Valovaya M.A., Popova T.I. 1979. [Study of invasion by helminths of the planktonic invertebrates of the White Sea] // Vestn. MGU. Ser. Biol. Vol.16. P.31-38 [in Russian].

Wardle W.J. 1975. Cercaria anadarae sp. n. parasitizing a bivalve mollusc, Anadara brasiliana (Lamarck), from the northwest Gulf of Mexico // J. Parasitol. Vol.61. No.6. P.1048-1049.

Weinstein M. 1966. Parasites of the chaetognath Sagitta elegans Verrill in the Gulf of St. Lawrence // Rapp. Ann. Stn Biol. mar Grand-Riviere. P.55-59.

Weinstein M. 1967. Endoparasites of the chaetognath Sagitta elegans Verrill in the Gulf of St. Lawrence // Rapp. Ann. Stn Biol. mar Grand-Riviere. P.47-53.

Responsible editor N.M. Biserova 